\title{
Trace Metals Assessment of Groundwater in Parts of Iwo Southwestern Nigeria Using Flame Atomic Absorption Spectrometry and Very Low Frequency Electromagnetic Methods
}

\author{
GODWIN OLADELE OLUTONA ${ }^{1 *}$, OLUFEMI A. ALAGBE ${ }^{2}$, \\ JOHN A.O. OYEKUNLE ${ }^{3}$ and ADEREMI O. OGUNFOWOKAN ${ }^{3}$
}

${ }^{1}$ Department of Chemistry and Industrial Chemistry, Bowen University, Iwo, Nigeria

${ }^{2}$ Department of Physics and Solar Energy, Bowen University, Iwo, Nigeria

${ }^{3}$ Department of Chemistry, Obafemi Awolowo University, Ile-Ife, Nigeria

delog2@yahoo.com

Received 26 March 2013 / Accepted 30 April 2013

\begin{abstract}
Assessment of groundwater samples obtained from shallow wells in different parts of Iwo was investigated for their trace metal levels in order to determine their portability status. Samples were collected for two months each during the peak periods of wet and dry seasons. The levels of trace metals in the samples were profiled using flame atomic absorption spectrophotometer and very low frequency electromagnetic (VLF) methods. The overall mean concentrations $(\mathrm{mg} / \mathrm{L})$ of these metals were of the order $\mathrm{Mn}(0.06 \pm 0.01)=\mathrm{Cu}(0.06 \pm 0.01)>\mathrm{Mg}(0.56 \pm 0.12)>\mathrm{Zn}(0.05 \pm 0.01)=\mathrm{Cr}$ $(0.05 \pm 0.06)>\mathrm{Fe}(0.03 \pm 0.01)>\mathrm{Cd}(0.02 \pm 0.01)>\mathrm{Pb}(0.01 \pm 0.02)=\mathrm{As}(0.01 \pm 0.00)>\mathrm{Hg}(0.00 \pm 0.00)$. The VLF electromagnetic applied showed that the metals found their ways into these wells through fractures and joints that characterised the study area. Seasonal mean levels showed no significant variations in most of the trace metals with exception of some non-essential trace elements. The findings revealed that the levels of $\mathrm{Mn}, \mathrm{Fe}, \mathrm{Cu}, \mathrm{Pb}, \mathrm{Cr}$ and $\mathrm{Cd}$ were either equal to or exceed the permissible limits while the remaining metals were below these limits.
\end{abstract}

Keywords: Contamination, Drinking water, Groundwater, Health risks, Pollution, Trace elements, Shallow wells, Spectrophotometer, Iwo, Nigeria

\section{Introduction}

Iwo, an ancient city in the Southwestern part of Nigeria, with small-scale industries, such as mechanized cassava processing, sachet/bottled water industries, smelting, mechanical workshop, quarry industries, wood processing industries, communication and transport industries and medium and large scale agricultural practices, in recent times, has witnessed a sharp rise in the development as evidence in the establishment of private University in 2002, private polytechnic, proliferation of banking industries as well as telecommunication industry. 
Transportation and traffic flow is increasing on daily basis as a result of sharp rise in human population. Increasing population accelerating directly and indirectly resource utilization and management has led to solid and liquid wastes generation as well as substantial air emission ${ }^{1}$. Consequently, automobile exhaust, combustion of fossil fuel, poor waste management are contributing to the anthropogenic sources of heavy metals in the Iwo metropolis and its environs. Improper management of solid waste introduced into the ecosystem can contribute large quantities of pollutants continuously percolating into ground water table ${ }^{1}$.

Early concerns over the quality of ground waters were focused mainly on dissolved minerals. But recently, trace organics and heavy metals have become the focus of concern because robust methods having ability to detect chemicals in minute concentrations have been developed and there is an increasing awareness of potentially hazardous risks to public health and the environment ${ }^{1-2}$. Trace organics and metals are contributed to ground water from a variety of natural and anthropogenic sources. Once liberated to ground water, element distributions are continually modified by complex geochemical and biological process ${ }^{3}$. In practice, very low frequency (VLF) electromagnetic method is useful for the investigation of ground water pollution since the dissolved solid content is directly related to conductivity ${ }^{4}$.

Unsafe water and poor sanitation account for 3.7\% of the global diseases, and $80 \%$ of all these diseases exists in the developing world. Diarrhoea alone accounted for the yearly death of 1.6 million people around the world ${ }^{5}$. The presence of these traces metals and other contaminants in ground water cause water to be unsafe for drinking purposes. Serious systemic problems can arise as a result of increased accumulation of dietary heavy metal in human body ${ }^{6}$. Some of the adverse health effects of trace metals include developmental retardation, different types of cancer, kidney damage, endocrine disruption, immunological disorders and even death ${ }^{6}$.

This study was aimed at assessing the trace metal levels of shallow well water being used as domestic water sources by the residents of Iwo. This was done with a view of ascertaining the safety level and hence, the portability status of drinking water sources available for people of Iwo.

\section{Experimental}

Iwo is the headquarter town of Iwo Local government Area of Osun State in the Southwestern geo-political zone of Nigeria. It is more or less a nodal town from which towns such as Ibadan, Ile-Ife, Gbongan, Ede, Osogbo and so on can readily be accessed. Iwo is located $35 \mathrm{Km}$ away from Osogbo (the Osun state capital) on Latitude $07^{\circ} \mathrm{N} 38^{\prime} \mathrm{N}$ and longitude $004^{\circ} 11^{\prime} \mathrm{E}$. It lies $10 \mathrm{~km}$ north of the Iwo railway station on the Lagos-Kano railroad and serves as home to about 120,919 people $^{7}$ who are largely of Yoruba descent and predominantly Muslim.

\section{Sample collection and pre-treatment}

Samples were collected from nine locations with partially protected shallow wells within Iwo town taking into consideration the population density and human activities in the particular area. The location of each well was recorded using a hand held Global Positioning System (GPS Extrex Model) (Table 1). All wells had headwall inner concrete lining and all have cemented surrounding. Sampling was done four times as follows: dry season (DS) January and February and rainy season (RS) - September and October. The samples were drawn with a plastic bucket. Prior to sampling, all glassware and sample bottles were washed with liquid detergents, rinsed with tap water and soaked in $10 \% \mathrm{HNO}_{3}$ for $48 \mathrm{~h}$. They were there after rinsed with distilled water to preclude trace metal contaminations. 
The plastic bottles meant for sampling were further rinsed thrice on site with well waters being sampled. About $2 \mathrm{~L}$ well water sample for physical and chemical parameters determination were collected monthly from each sampling location. The collected samples were filtered using Whatman No. 42 filter paper and preserved with $6 \mathrm{~N}$ of $\mathrm{HNO}_{3}$ for further analysis ${ }^{8}$.

Table 1. GPS coordinate of the sampling locations in Iwo

\begin{tabular}{llllcc}
\hline Location & \multicolumn{1}{c}{ Activity } & E coordinates & N coordinate & $\begin{array}{c}\text { Elevation } \\
(\mathrm{m})\end{array}$ & $\begin{array}{c}\text { Well } \\
\text { Depth (m) }\end{array}$ \\
\hline $\begin{array}{l}\text { Adeeke } \\
\text { Asabi- }\end{array}$ & Densely populated area & $004^{\circ} 09.641^{\prime}$ & $07^{\circ} 37.873^{\prime}$ & 237.74 & 5.49 \\
Okin & Thinly populated area & $004^{\circ} 12.500^{\prime}$ & $07^{\circ} 38.057^{\prime}$ & 261.21 & 4.17 \\
Kuti & $\begin{array}{l}\text { Densely populated area } \\
\text { Heavy traffic/ }\end{array}$ & $004^{\circ} 10.476^{\prime}$ & $07^{\circ} 38.254^{\prime}$ & 259.99 & 5.49 \\
Odo-Ori & $\begin{array}{l}\text { commercial centre/ } \\
\text { motor park area }\end{array}$ & $004^{\circ} 11.022^{\prime}$ & $07^{\circ} 9.373^{\prime}$ & 245.36 & 3.94 \\
& $\begin{array}{l}\text { Heavy } \\
\text { traffic/commercial }\end{array}$ & $004^{\circ} 10.878^{\prime}$ & $07^{\circ} 38.109^{\prime}$ & 253.59 & 3.42 \\
Oja-Oba & $\begin{array}{l} \\
\text { centre/motor park area }\end{array}$ & $004^{\circ} 10.834^{\prime}$ & $07^{\circ} 37.320^{\prime}$ & 227.08 & 5.49 \\
$\begin{array}{l}\text { Oke-Afo } \\
\text { Oke-Odo } \\
\text { Technical }\end{array}$ & $\begin{array}{l}\text { Densely populated area populated area } \\
\text { Thinly populated area }\end{array}$ & $004^{\circ} 11.068^{\prime}$ & $07^{\circ} 39.361^{\prime}$ & 121.92 & 4.88 \\
Water & Densely populated area & $004^{\circ} 12.320^{\prime}$ & $07^{\circ} 37.497^{\prime}$ & 238.66 & 4.88 \\
Works & $07^{\circ} 37.251^{\prime}$ & 198.12 & 5.49 \\
\hline
\end{tabular}

\section{Sample analysis}

To ensure removal of organic impurities and thereby prevent interference analysis, the samples were digested with concentrated nitric acid. Accurately measured $5 \mathrm{~mL}$ concentrated $\mathrm{HNO}_{3}$ was added to $50 \mathrm{~mL}$ of water sample in a Teflon beaker. The mixture was heated and allowed to evaporate at a temperature of about $130{ }^{\circ} \mathrm{C}$ on a thermostated hot plate to near dryness. Thereafter, it was allowed to cool and then filtered into a $50 \mathrm{~mL}$ standard flask and made up to mark with doubly distilled water. The digested water samples were analyzed for their metal contents using a Buck Model 205 Flame Atomic Absorption spectrophotometer (FAAS), East Norwalk, United State of America available at the International Institute of Tropical Agriculture (IITA), Ibadan, Nigeria.

\section{Quality assurance protocol}

\section{Blank determination}

Blank experiments were run to check for background contaminants by the reagents and apparatus used. The values obtained from running blank experiments were subtracted from the analyte values as applicable.

\section{Calibration of instrument}

The calibration of the FAAS used was done to evaluate the response of the analytical procedure with respect to known quantities of the standards of the heavy metals of interest so that the response to unknown quantities in the samples could be reliably estimated. For the FAAS $20,18,16,14,12,10,8,6,4,2$ and $0 \mu \mathrm{g} / \mathrm{L}$ concentrations of each metal solution were prepared by serial dilution for the determination of metals in soil samples. These solutions were run to obtain the working calibration graph. FAAS was used to estimate the levels of heavy metals in the samples by automatic interpolation with respect to the calibration graph. 


\section{Recovery analysis}

This was conducted to assess the error levels arising from contamination and adsorption losses in the speciation procedure and also to ascertain the precision of the analytical procedures used in this study. A $25 \mathrm{~mL}$ water sample was put into a Teflon beaker and was spiked with $25 \mathrm{~mL}$ of $50 \mu \mathrm{g} / \mathrm{mL}$ of the metals and digested as earlier described. The digested spiked sample was made up to the mark in a $25 \mathrm{~mL}$ volumetric flask with doubly distilled water. Also, a $25 \mathrm{~mL}$ each of $50 \mu \mathrm{g} / \mathrm{mL}$ of the standard heavy metal solution mixture was also prepared. The two samples were subjected to the same sample digestion procedures. The digested solution was quantitatively added to a $25 \mathrm{~mL}$ volumetric flask. The levels of each of these metals in the two samples were determined using the FAAS. The percentage recovery $(\% \mathrm{R})$ for each metal was calculated using the relationship:

$$
\% \mathrm{R}=\frac{\mathrm{A}-\mathrm{B}}{\mathrm{C}} \times 100
$$

Where $\mathrm{A}=$ concentration of a metal in the spiked sample; $\mathrm{B}=$ concentration of a metal in the unspiked sample and $\mathrm{C}=$ the amount of metal (ppm) used for spiking.

\section{Statistical analysis of data}

The mean and standard deviation for the metals from three replicate measurements was determined using statistical package for social science (SPSS) software, 15.0 for window evaluation version. Trace metal analysis were subjected to one-way analysis of variance. Duncan's multiple range test ${ }^{9}$ was used to determine significant differences between treatment means. The linear correlation coefficient of the trace metals was determined using the Pearson correlation coefficient. Factor analysis was also carried out.

\section{Very low frequency (VLF) electromagnetic analysis}

VLF electromagnetic measurements were made over the study area, using ABEM Wadi. This method relies on navigational transmission from remote antennas which cause secondary fields to build up around conductive structures. It is used for locating vertical features such as fracture zones and geologic contacts as well as in contaminant plume mapping ${ }^{10}$. In the field produce, the frequency of a station is selected and the current input recorded. The instrument is tilted around until a good signal is obtained and the tilt of the coil recorded. This gives the ration of real (Re) to imaginary (IM). The ratio of the amplitude of real (Re) and imaginary (IM) components of the secondary field is related to phase angle. The greater the Re/IM ratio, the better is the conductor or structure.

The WADI instrument is tilted with a software which automatically gives a filter real (FRe) and filter imaginary (FIM). The VLF readings are plotted by using computer software and the graphs interpreted.

\section{Results and Discussion}

Table 1 present the geographic regional distribution and the map of the sampled area for trace metal analysis. Distribution of trace metals examined in this study at various locations results are shown in Table 2 . The overall mean concentrations $(\mathrm{mg} / \mathrm{L})$ of these metals are in decreasing order of $\mathrm{Mn}(0.06 \pm 0.01)=\mathrm{Cu}(0.06 \pm 0.01)>\mathrm{Mg}(0.56 \pm 0.12)>\mathrm{Zn}(0.05 \pm 0.01)=$ $\mathrm{Cr}(0.05 \pm 0.06)>\mathrm{Fe}(0.03 \pm 0.01)>\mathrm{Cd}(0.02 \pm 0.01)>\mathrm{Pb}(0.01 \pm 0.02)=\mathrm{As}(0.01 \pm 0.00)>\mathrm{Hg}$ $(0.00 \pm 0.00)$. 
Table 2. Value of recovery analysis and calibration curve

\begin{tabular}{ccccccccccc}
\hline & $\mathrm{Fe}$ & $\mathrm{Mn}$ & $\mathrm{Zn}$ & $\mathrm{Cu}$ & $\mathrm{Pb}$ & $\mathrm{Hg}$ & $\mathrm{As}$ & $\mathrm{Cd}$ & $\mathrm{Cr}$ & $\mathrm{Mg}$ \\
\hline $\mathrm{r}^{2}$ & 0.9961 & 0.9898 & 0.9896 & 0.9794 & 0.9585 & 0.9856 & 0.9987 & 0.9975 & 0.9892 & 0.9973 \\
\hline$\% \mathrm{R}$ & $87.50 \pm 6.60$ & $89.73 \pm 6.31$ & $98.38 \pm 6.97$ & $96.23 \pm 3.06$ & $86.99 \pm 3.53$ & $84.72 \pm 4.02$ & $92.88 \pm 3.54$ & $92.99 \pm 4.55$ & $89.15 \pm 3.97$ & $93.20 \pm 3.91$ \\
\hline
\end{tabular}

${ }^{*}$ Value $=$ mean of triplicate analysis \pm s.d.

Table 3. Mean levels of trace metals of ground water of Iwo metropolis

\begin{tabular}{|c|c|c|c|c|c|c|c|c|c|c|}
\hline & $\mathrm{Mg}$ & $\mathrm{Mn}$ & $\mathrm{Fe}$ & $\mathrm{Zn}$ & $\mathrm{Cu}$ & $\mathrm{Pb}$ & $\mathrm{Hg}$ & As & $\mathrm{Cd}$ & $\mathrm{Cr}$ \\
\hline Adeeke & $0.45 \pm 0.05^{\mathrm{a}}$ & $0.06 \pm 0.01^{b}$ & $0.03 \pm 0.01^{\mathrm{a}}$ & $0.05 \pm 0.01^{\mathrm{ab}}$ & $0.06 \pm 0.01^{b}$ & $0.01 \pm 0.00^{\mathrm{a}}$ & $0.00 \pm 0.00^{\mathrm{a}}$ & $0.01 \pm 0.00^{\mathrm{ab}}$ & $0.01 \pm 0.00^{\mathrm{a}}$ & $0.04 \pm 0.05^{\mathrm{a}}$ \\
\hline $\begin{array}{l}\text { Asabi- } \\
\text { Okin }\end{array}$ & $0.61 \pm 0.10^{b c}$ & $0.06 \pm 0.01^{b}$ & $0.03 \pm 0.01^{\mathrm{a}}$ & $0.05 \pm 0.01^{\mathrm{ab}}$ & $0.05 \pm 0.01^{\mathrm{a}}$ & $0.01 \pm 0.00^{\mathrm{a}}$ & $0.01 \pm 0.00^{\mathrm{abc}}$ & ${ }^{\mathrm{c}} 0.01 \pm 0.00^{\mathrm{ab}}$ & $0.01 \pm 0.00^{\mathrm{a}}$ & $0.04 \pm 0.04^{\mathrm{a}}$ \\
\hline Kuti & $0.52 \pm 0.11^{\mathrm{ab}}$ & $0.06+0.01^{\mathrm{ab}}$ & $0.03 \pm 0.01^{\mathrm{a}}$ & $0.06 \pm 0.01^{b}$ & $0.07 \pm 0.01^{\mathrm{b}}$ & $0.01 \pm 0.00^{\mathrm{a}}$ & $0.00 \pm 0.00^{\mathrm{abc}}$ & ${ }^{\mathrm{c}} 0.01 \pm 0.00^{\mathrm{ab}}$ & $0.01 \pm 0.00^{\mathrm{a}}$ & $0.06 \pm 0.08^{\mathrm{a}}$ \\
\hline Odo-Ori & $0.56 \pm 0.09^{\mathrm{ab}}$ & $0.06 \pm 0.01^{\mathrm{ab}}$ & $0.03 \pm 0.01^{\mathrm{a}}$ & $0.05 \pm 0.01^{\mathrm{ab}}$ & $0.07 \pm 0.01^{b}$ & $0.01 \pm 0.00^{\mathrm{a}}$ & $0.00 \pm 0.00^{\mathrm{abc}}$ & ${ }^{\mathrm{c}} 0.01 \pm 0.00^{\mathrm{ab}}$ & $0.01 \pm 0.00^{\mathrm{a}}$ & $0.04 \pm 0.04^{\mathrm{a}}$ \\
\hline Oja-Oba & $0.58 \pm 0.06^{b c}$ & $0.06 \pm 0.01^{\mathrm{ab}}$ & $0.03 \pm 0.00^{\mathrm{a}}$ & $0.05 \pm 0.01^{\mathrm{ab}}$ & $0.07 \pm 0.01^{b}$ & $0.01 \pm 0.00^{\mathrm{a}}$ & $0.00 \pm 0.00^{\mathrm{ab}}$ & $0.01 \pm 0.00^{\mathrm{ab}}$ & $0.01 \pm 0.00^{\mathrm{a}}$ & $0.07 \pm 0.10^{\mathrm{a}}$ \\
\hline Oke-Afo & $0.52 \pm 0.09^{\mathrm{ab}}$ & $0.07 \pm 0.02^{b}$ & $0.03 \pm 0.01^{\mathrm{a}}$ & $0.04 \pm 0.01^{\mathrm{a}}$ & $0.06 \pm 0.01^{\mathrm{ab}}$ & $0.01 \pm 0.00^{\mathrm{a}}$ & $0.01 \pm 0.00^{\mathrm{bc}}$ & ${ }^{\mathrm{c}} 0.01 \pm 0.00^{\mathrm{a}}$ & $0.01 \pm 0.00^{\mathrm{a}}$ & $0.05 \pm 0.06^{\mathrm{a}}$ \\
\hline Oke-Odo & $0.54 \pm 0.16^{\mathrm{ab}}$ & $0.05 \pm 0.00^{\mathrm{a}}$ & $0.03 \pm 0.00^{\mathrm{a}}$ & $0.05 \pm 0.01^{\mathrm{ab}}$ & $0.06 \pm 0.01^{\mathrm{ab}}$ & $0.01 \pm 0.00^{\mathrm{a}}$ & $0.01 \pm 0.01^{\mathrm{c}}$ & $0.01 \pm 0.00^{\mathrm{ab}}$ & $0.02 \pm 0.00^{\mathrm{a}}$ & $0.04 \pm 0.05^{\mathrm{a}}$ \\
\hline Technical & $0.60 \pm 0.12^{\mathrm{bc}}$ & $0.06 \pm 0.01^{\mathrm{ab}}$ & $0.03 \pm 0.00^{\mathrm{a}}$ & $0.05 \pm 0.01^{\mathrm{ab}}$ & $0.06 \pm 0.01^{b}$ & $0.03 \pm 0.04^{b}$ & $0.00 \pm 0.00^{\mathrm{ab}}$ & $0.01 \pm 0.00^{\mathrm{b}}$ & $0.01 \pm 0.00^{\mathrm{a}}$ & $0.01 \pm 0.01^{\mathrm{a}}$ \\
\hline $\begin{array}{l}\text { Water } \\
\text { Works }\end{array}$ & $0.69 \pm 0.12^{\mathrm{c}}$ & $0.06 \pm 0.00^{\mathrm{b}}$ & $0.04 \pm 0.01^{\mathrm{a}}$ & $0.05 \pm 0.01^{\mathrm{ab}}$ & $0.06 \pm 0.01^{\mathrm{ab}}$ & $0.01 \pm 0.01^{\mathrm{a}}$ & $0.00 \pm 0.00^{\mathrm{ab}}$ & $0.01 \pm 0.00^{\mathrm{ab}}$ & $0.03 \pm 0.04^{b}$ & $0.05 \pm 0.07^{\mathrm{a}}$ \\
\hline $\operatorname{Mean} \pm$ sd & $0.56 \pm 0.12$ & $0.06 \pm 0.01$ & $0.03 \pm 0.01$ & $0.05 \pm 0.01$ & $0.06 \pm 0.01$ & $0.01 \pm 0.02$ & $0.00 \pm 0.00$ & $0.01 \pm 0.00$ & $0.02 \pm 0.01$ & $0.05 \pm 0.06$ \\
\hline Range & $0.40-0.81$ & $0.05-0.09$ & $0.02-0.05$ & $0.03-0.07$ & $0.04-0.08$ & $0.01-0.10$ & $0.00-0.02$ & $0.00-0.01$ & $0.01-0.10$ & $0.01-0.23$ \\
\hline
\end{tabular}

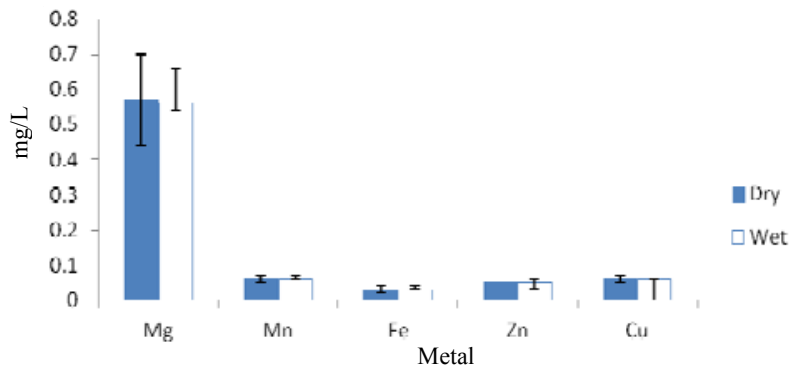

Figure 1. Seasonal variation in essential trace metals in nine different locations of Iwo 
The result of the recovery analysis of metal analysed for water samples drawn from all the five locations are presented in Table 2 below and discussed accordingly. Under the experimental conditions used, the standard calibration curves obtained showed high linearity level with $\mathrm{r}^{2}$ values between 0.9585 for $\mathrm{Pb}$ and 0.9973 for $\mathrm{Mg}$. Recoveries of trace metals in water ranged from $84.72 \pm 4.02 \%$ for $\mathrm{Hg}$ to $98.38 \pm 6.97 \%$ for $\mathrm{Zn}$. These values are adjudged acceptable and hence, the results obtained are reliable.

\section{Trace metal analysis}

Magnesium is regarded as essential for human nutrition because it is an activator and constituent of many enzymes present in humans ${ }^{11}$. It is the second most common intracellular cation in the body and is required as a cofactor for more than 300 enzymatic reactions in order to maintain normal physiologic processes. Also, many steps involved in the synthesis of DNA and RNA require magnesium and it is very useful in stabilizing these macromolecules ${ }^{12}$. Some of the diseases caused by magnesium deficiency include cardiac arrhythmias, coronary artery disease, diabetes milletus, fasciculation and tremor ${ }^{12}$. The concentration of Magnesium $(\mathrm{Mg})$ in this study ranged from 0.40 to $0.81 \mathrm{mg} / \mathrm{L}$ with a mean value of $0.56 \pm 0.12 \mathrm{mg} / \mathrm{L}$ (Table 3). There was no significant different in the seasonal variation of Magnesium (Figure 1).

Manganese (Mn) occurs naturally as a mineral from sediment and rocks or from mining and industrial waste1.Excess concentrations of Mn make water distasteful to drinking with no specific toxic effects ${ }^{13-14}$. Although, $\mathrm{Fe}$ and $\mathrm{Mn}$ are usually found together in ground water supplies, $\mathrm{Mn}$ has been shown to exceed aesthetic objectives more frequently than $\mathrm{Fe}^{13}$. The concentrations of $\mathrm{Mn}$ varied between 0.05 and $0.09 \mathrm{mg} / \mathrm{L}$ with a mean value of $0.06 \pm 0.01 \mathrm{mg} / \mathrm{L}$ (Table 2). The ground water quality standard of $\mathrm{Mn}$ desirable and permissible limit is $0.05 \mathrm{mg} / \mathrm{L}^{5}$. The mean concentration of $\mathrm{Mn}$ obtained in this study exceeded the desirable and permissible limit as specified by WHO.

Ground water contains variable amounts of iron (Fe) depending on the geologic area, industrial wastes, domestic discharge and other chemical components of the aquifer. Iron can cause aesthetic problems such as staining of laundry and fixtures and can impart a bitter taste to water ${ }^{1-15}$. The levels of Fe from $0.02-0.05 \mathrm{mg} / \mathrm{L}$ with a mean value of $0.03 \pm 0.01 \mathrm{mg} / \mathrm{L}$ (Table 3). There was no significant difference between dry and wet season values of $\mathrm{Fe}$ (Figure 1). The mean value obtained in this study was equal to the recommended limit $(0.3 \mathrm{mg} / \mathrm{L})$ as stipulated by the WHO. Excess amount of iron (more than $10 \mathrm{mg} / \mathrm{kg}$ ) causes rapid increase in pulse rate and coagulation of blood vessels, hypertension and drowsiness ${ }^{15}$.

Zinc $(\mathrm{Zn})$ is found naturally in water, most frequently in areas where it is mined and from industrial waste, metal plating, plumbing and is a major component of sludge ${ }^{1}$. The concentrations of $\mathrm{Zn}$ in our study ranged from $0.03-0.07 \mathrm{mg} / \mathrm{L}$ with mean value of $0.05 \pm 0.01 \mathrm{mg} / \mathrm{L}$ (Table 3 ). There was no significant difference in the seasonal variations (Figure 1). The WHO ground water quality standard of $\mathrm{Zn}$ desirable limit is $5.0 \mathrm{mg} / \mathrm{L}$ and maximum permissible limit is $10.0 \mathrm{mg} / \mathrm{L}$. The values obtained in all locations in this study were below the desirable and maximum permissible limits as recommended by $\mathrm{WHO}^{5}$.

Copper enters into water bodies and other environmental compartments mostly through anthropogenic activities such as metal plating, industrial and domestic waste, mining and mineral leaching ${ }^{1}$. Copper accumulates in liver and brain ${ }^{15}$. Copper toxicity is a fundamental cause of Wilson diseases ${ }^{16}$. The levels of $\mathrm{Cu}$ in our study ranged from 0.04-0.08 mg/L with a mean value of $0.06 \pm 0.01 \mathrm{mg} / \mathrm{L}$ (Table 3 ). Seasonal variations showed no significant difference between the two seasons (Figure 1). The WHO desirable limit of $\mathrm{Cu}$ in ground water is $0.05 \mathrm{mg} / \mathrm{L}$ while the maximum permissible limit is $2.0 \mathrm{mg} / \mathrm{L}^{5}$. The concentrations of 
$\mathrm{Cu}$ obtained in this study from all locations were above the desirable limit but below the maximum permissible limit as stipulated by the $\mathrm{WHO}^{5}$. Hence, continuous dependence of the populace on the untreated ground water supply of the study area may later manifest in the development of copper-induced health symptoms.

Lead is a highly toxic naturally occurring metal that has always been present in soils, surface waters and ground waters and can cause serious problems especially for infants, children and pregnant women ${ }^{17}$. It enters into the environment from industry, mining, plumbing, gasoline, coal and as a water additive, different waste and household sewage ${ }^{1-15}$. Toxic level of $\mathrm{Pb}$ in human body is $500 \mathrm{ppm}$ beyond which it causes anaemia, brain damage and vomiting ${ }^{16}$. Further, Shuhaimi-Othmnan ${ }^{18}$ noted that the adverse effects of $\mathrm{Pb}$ consist of manifestation of cancers, adverse reproductive outcomes, cardiovascular and neurological diseases. The concentrations of $\mathrm{Pb}$ in this study ranged from $0.01-1.0 \mathrm{mg} / \mathrm{L}$ with a mean value of $0.01 \pm 0.02 \mathrm{mg} / \mathrm{L}$. The concentration of $\mathrm{Pb}$ for wet season was significantly higher than dry season value (Figure 2). This might be due to runoffs from roads, soils and agricultural areas during the rainy season. The ground water quality standard of $\mathrm{Pb}$ for both desirable and permissible limit as stipulated by $\mathrm{WHO}^{5}$ is 0.01 $\mathrm{mg} / \mathrm{L}$. In all locations, the $\mathrm{Pb}$ values were equal to the desirable and permissible limits with exception of Technical area $(0.03 \pm 0.01 \mathrm{mg} / \mathrm{L})$ which was above the recommended limit.

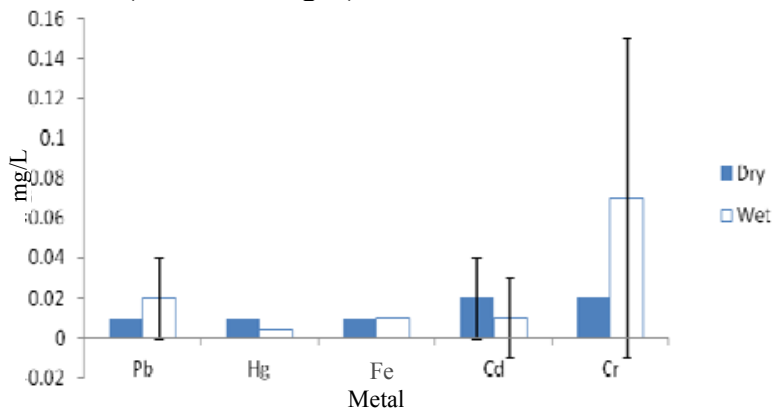

Figure 2. Seasonal variation in non-essential trace metals in nine different locations in Iwo

Mercury occurs as an inorganic salt and as organic mercury compounds. It enters into the environment from industrial waste, mining, pesticides, electrical equipment (batteries, lamp and switches), smelting and fossil fuel combustion ${ }^{1}$. The concentrations of $\mathrm{Hg}$ ranged from $0.00-0.02 \mathrm{mg} / \mathrm{L}$ with a mean value of $0.00 \pm 0.00 \mathrm{mg} / \mathrm{L}$ (Table 3). The ground water quality standard of $\mathrm{Hg}$ for both desirable and permissible limits as stipulated by $\mathrm{WHO}^{5}$ is $0.006 \mathrm{mg} / \mathrm{L}$. This study indicated that the $\mathrm{Hg}$ level was below the permissible and desirable limits. However, because of its high toxicity and tendency to bioaccumulate to health-threatening levels within a short period, caution must be exercised to ensure proper treatment of water that precludes the presence or total removal of $\mathrm{Hg}$ in water meant for domestic purposes.

Arsenic enters the environment from natural processes, industrial activities, pesticides, and industrial waste, smelting of copper, lead and zinc ore ${ }^{1}$. The main adverse health effects of as are tracheae bronchitis, rhinitis, pharyngitis, shortness of breath and nasal congestion ${ }^{19}$. Similarly, contamination of drinking water by as may also result in black foot disease ${ }^{20}$. The concentration of As in our study range from $0.00-0.01 \mathrm{mg} / \mathrm{L}$ with a mean value of $0.01 \pm 0.00 \mathrm{mg} / \mathrm{L}$. Seasonal variations of As in the water samples showed no significant difference at $\mathrm{P} \leq 0.05$ (Figure 2). The ground water quality standard of as desirable and permissible limit $\mathrm{WHO}^{5}$ is $0.01 \mathrm{mg} / \mathrm{L}$. This study demonstrated that the as levels were equivalent to the permissible and desirable limit. 
Cadmium found in low concentrations in rocks, coal and petroleum can enter ground and surface waters and general environment from industrial discharge, mining waste, metal plating, water pipes, batteries, paints and pigments, plastic stabilizers and land fill leachate ${ }^{1}$. The concentration of $\mathrm{Cd}$ in this study ranged between 0.01 and $0.10 \mathrm{mg} / \mathrm{L}$ with a mean value of $0.02 \pm 0.01 \mathrm{mg} / \mathrm{L}$. The seasonal variations showed that the dry season mean value $(0.02 \pm 0.02)$ was significantly higher, at $\mathrm{P} \leq 0.05$, than wet season value $(0.01 \pm 0.02)$ (Figure 2$)$. The ground water quality standard of Cd desirable and permissible limit $\mathrm{WHO}^{5}$ is $0.003 \mathrm{mg} / \mathrm{L}$. The mean value of $\mathrm{Cd}$, obtained in this study was above the desirable and permissible limit. Elevated concentrations of $\mathrm{Cd}$ can cause nausea, vomiting, salivation, renal and kidney failure, liver and blood damages, skeletal deformities and genetic mutations ${ }^{21}$.

Chromium is essential for organisms as a micronutrient for fat and carbohydrate metabolism ${ }^{15}$. Chromium enters the environment from old mining operation, runoff and leaching into ground water, fossil fuel combustion, cement plant emission, mineral leaching and waste incineration ${ }^{1}$. The concentration of $\mathrm{Cr}$ in this study ranged from $0.01-0.23 \mathrm{mg} / \mathrm{L}$ with a mean value of $0.05 \pm 0.06 \mathrm{mg} / \mathrm{L}$. The seasonal variations showed that the mean value of $\mathrm{Cr}$ in wet season level $(0.07 \pm 0.08 \mathrm{mg} / \mathrm{L})$ was significantly higher, at $\mathrm{P} \leq 0.05$, than the dry season level $(0.02 \pm 0.00 \mathrm{mg} / \mathrm{L})$ (Figure 2$)$. The ground water quality standard of $\mathrm{Cr}$ desirable and permissible limit is $0.05 \mathrm{mg} / \mathrm{L}$. In this study, higher concentrations of $\mathrm{Cr}$ were observed in samples from Kuti, Oke-Afo, Oja-Oba and Water Works areas of Iwo. In a similar way, mean value of $\mathrm{Cr}$ was above the permissible level in wet season (Figure 2). The presence of high concentration of $\mathrm{Cr}$ (III) and heavy doses of chromium salts, even though are rapidly eliminated from human body, corrode the intestinal tract ${ }^{22}$ and are potential carcinogens ${ }^{15}$.

\section{Correlation analysis}

The result of two-tailed Pearson correlation matrix of the trace metal analyzed is shown in Table 4. This result showed that $\mathrm{Mg}$ was positively correlated with $\mathrm{Cu}$ and $\mathrm{Cd}$ at 0.01 and 0.05 level while negatively correlated with $\mathrm{Hg}$ at 0.05 levels. Mn was positively correlated with $\mathrm{Fe}$ and $\mathrm{Hg}$ at 0.01 levels. Fe was negatively correlated with $\mathrm{Zn}$ and $\mathrm{Cd}$ both at 0.01 and 0.05 levels but positively correlated with $\mathrm{Cr}$ at 0.01 levels. $\mathrm{Zn}$ was positively correlated with $\mathrm{Cu}$ and negatively correlated with $\mathrm{Cr}$ both at 0.05 and 0.01 levels respectively. $\mathrm{Cu}$ was negatively correlated with As at 0.01 level. Similarly As was negatively correlated with $\mathrm{Cr}$ at 0.01 level.

Table 4. Two tailed pearson correlation analysis

\begin{tabular}{lllllllllll}
\hline & $\mathrm{Mg}$ & $\mathrm{Mn}$ & $\mathrm{Fe}$ & $\mathrm{Zn}$ & $\mathrm{Cu}$ & $\mathrm{Pb}$ & $\mathrm{Hg}$ & $\mathrm{As}$ & $\mathrm{Cd}$ & $\mathrm{Cr}$ \\
\hline $\mathrm{Mg}$ & 1 & & & & & & & & & \\
$\mathrm{Mn}$ & 0.043 & 1 & & & & & & & & \\
$\mathrm{Fe}$ & -0.065 & $0.338^{* *}$ & 1 & & & & & & & \\
$\mathrm{Zn}$ & 0.014 & 0.062 & $-0.316^{* *}$ & 1 & & & & & & \\
$\mathrm{Cu}$ & $0.302^{* *}$ & -0.008 & -0.197 & $0.294^{*}$ & 1 & & & & & \\
$\mathrm{~Pb}$ & 0.048 & -0.018 & 0.182 & -0.186 & -0.121 & 1 & & & & \\
$\mathrm{Hg}$ & $-0.291^{*}$ & $0.376^{* *}$ & 0.159 & -0.158 & -0.166 & -0.032 & 1 & & & \\
$\mathrm{As}$ & 0.144 & 0.117 & 0.044 & 0.114 & $-0.348^{* *}$ & 0.214 & -0.025 & 1 & & \\
$\mathrm{Cd}$ & $0.283^{*}$ & 0.042 & $-0.266^{*}$ & 0.004 & -0.107 & 0.116 & -0.191 & 0.066 & 1 & \\
$\mathrm{Cr}$ & 0.109 & 0.033 & $0.372^{* *}$ & $-0.446^{* *}$ & 0.156 & -0.092 & -0.068 & $-0.355^{* *}$ & 0.052 & 1 \\
\hline
\end{tabular}

${ }^{* *}$ Correlation is significant at the 0.01 level (2-tailed), ${ }^{*}$ Correlation is significant at the 0.05 level (2-tailed)

The above association can be explained in terms of a common source or by chemical similarity. Knudso et al., ${ }^{23}$ thus positive correlation between these metals could indicate a 
common source. The inter-element positive correlation between all metals could possibly suggest that the elemental association is controlled by factors such as soil gneisses, properties and anthropogenic inputs ${ }^{24}$.

\section{Principal component analysis (PCA)}

The principal component analysis (PCA) is a powerful pattern recognition technique that attempts to explain the variance of a large dataset of interrelated variable ${ }^{25}$. PCA was employed on the trace metal to compare the compositional pattern between the examined trace metal and to identify the factors that influenced each one. For the trace metals, as apparently indicated in Figure 3, the most plausible factors for the presence of trace metals are weathering of based rocks in addition to anthropogenic inputs. The pattern of association was also clearly illustrated, for the first component $\mathrm{Fe}$ and $\mathrm{Hg}$ were strongly associated while the second component $\mathrm{Cr}$ and $\mathrm{Cu}$ were strongly associated.

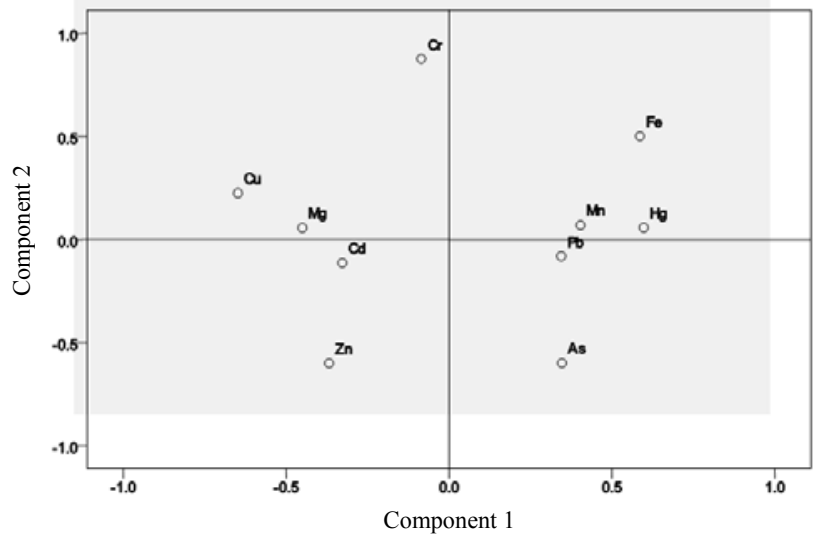

Figure 3. Factor analysis for trace metals in shallow well waters in Iwo

\section{VLF data analysis}

VLF data were collected along four profiting lines at the study site. Graphs of Real Raw, R versus position $(\mathrm{M})$ and Filtered Raw versus position $(\mathrm{M})$ were plotted for each transverse Figures 4 to 8 . The interpretation of the graphs revealed the followings:

Seven positive peaks were observed on profile 1 (Figure 4) corresponding to regions of conductive zones, profile 1 covered a total distance of approximately $145 \mathrm{~m}$. The second profile (Figure 5), covered a distance of $150 \mathrm{~m}$. Four positive peaks were observed along this profile. Two peaks of relatively small value were observed between $85-90 \mathrm{~m}$ and 110-115 $\mathrm{m}$. These peaks were also indicative of presence of contaminant plumes.

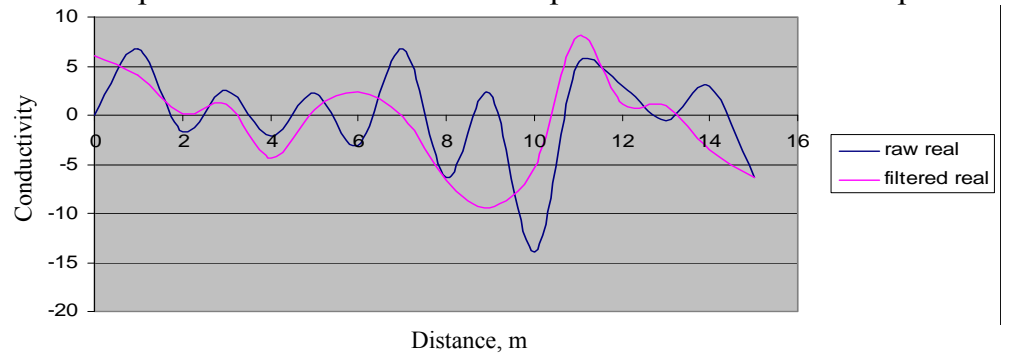

Figure 4. Real raw and filtered raw versus position (m) for profile $1(\mathrm{~S}-\mathrm{N})$ 


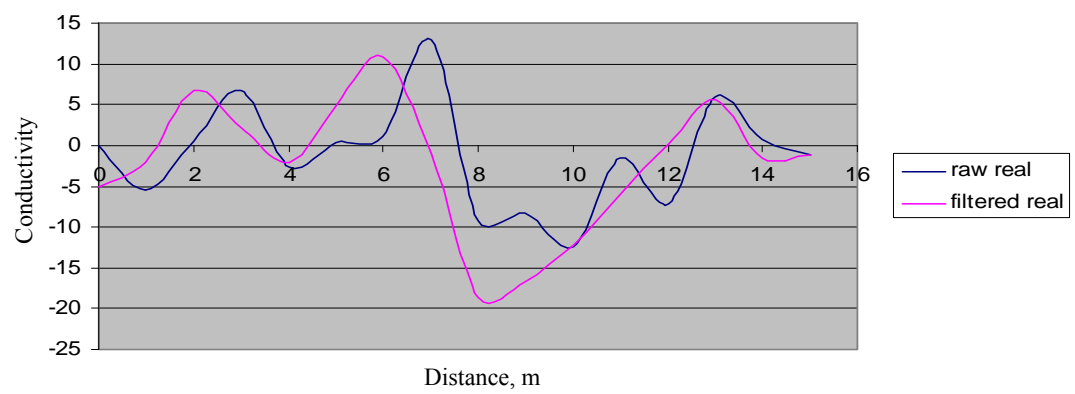

Figure 5. Real raw and filtered raw versus position $(\mathrm{m})$ for profile $2(\mathrm{~S}-\mathrm{N})$

The third profile (Figure 6) covers a total distance of $200 \mathrm{~m}$. The profile consist of five high positive peaks along the profile line and two small peaks between 0-10 $\mathrm{m}$ and 170-180 $\mathrm{m}$. These positive peaks are weak zones prone to contamination.

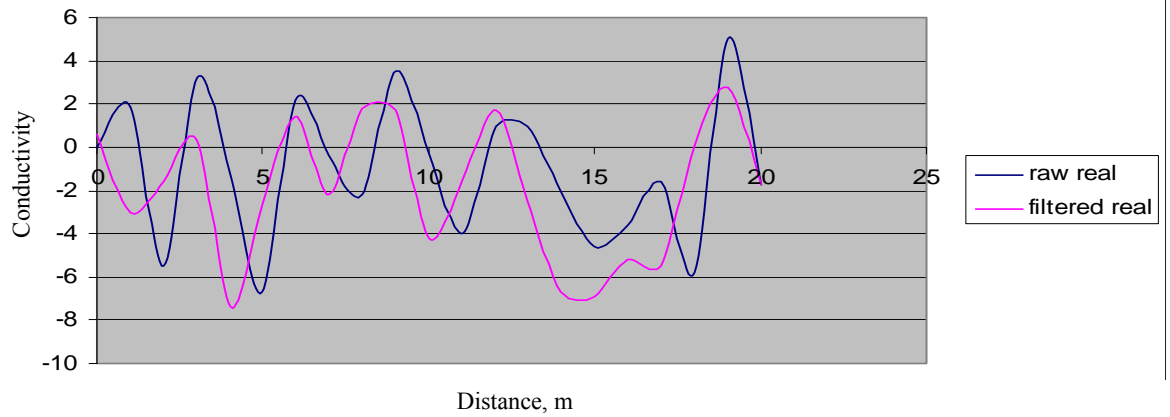

Figure 6. Real raw and filtered raw versus position $(\mathrm{m})$ for profile $3(\mathrm{~S}-\mathrm{N})$

The fourth profile (Figure 7) has a total of three observed high peaks and three small positive peaks. The profile covers a total distance of $150 \mathrm{~m}$. Also, these positive peaks are suspected conductive zones characterised by contaminants or weak zones.

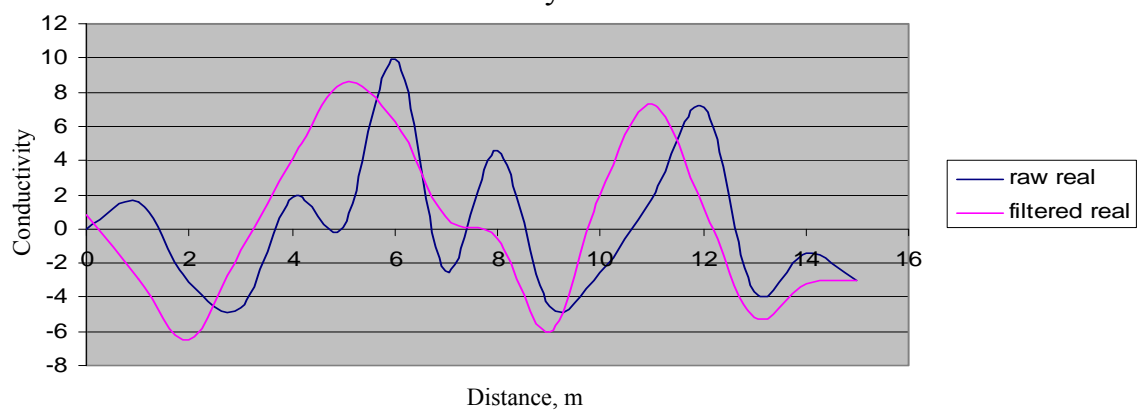

Figure 7. Real raw and filtered raw versus position (m) for profile $4(\mathrm{E}-\mathrm{W})$

A $2 \mathrm{D}$ contour map of the study area is as shown in Figure 8 . The zone with positive conductivity value $0-8 \mathrm{~m}$ (blue contour) has a wide spread within the area. The highest positive values $8-18 \mathrm{~m}$ (pink colour) were observed at two locations, the South-East and North central. These two zones showed the possible high levels of conductivity which corresponds to areas of high level of contaminants. Conclusively, the North-East trend west, and trending towards the southern part of the study area are prone to contamination while the south eastern part is most prone to contamination. 


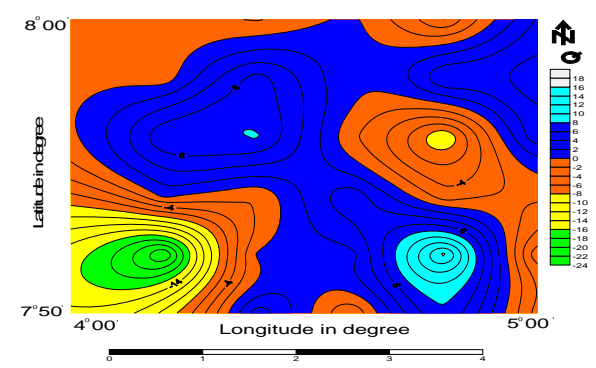

Figure 8. Contour Map of the study area

\section{Conclusion}

Assessment of trace metals in shallow-well water used for drinking purposes in different parts of Iwo was investigated using FAAS and VLF electromagnetic methods. The analysis of water samples collected from nine representative wells within the town showed no significant seasonal variations for nearly all the trace metals with exception of some nonessential trace elements. These findings revealed that trace metals like $\mathrm{Mn}, \mathrm{Fe}, \mathrm{Cu}, \mathrm{Pb}, \mathrm{Cr}$ and $\mathrm{Cd}$ analysed were equal to or exceeded the WHO desirable and permissible limits while the other metals were had concentrations that fell below the WHO limit. The VLF method revealed the study area to be segmented with features such as fracture fault zones and geologic contact that provides seepage paths into underground water. It is therefore recommended that some kind of inexpensive treatment of the ground water be adopted to reduce the levels of trace metals especially those that were above the permissible limits. Constant monitoring is also recommended to avoid further degradation of the water quality.

\section{References}

1. Reddy T B, Ch. Venkata Ramana, Ch. Bhaskar and Jagadeesh Chandrababu P, Int J Sci Nat., 2012, 3(2), 468-471.

2. Alabdula'aly A I, Al Zarah A I and Khan M A, Int J Wat Resour Arid Environ., 2011, 1(1), 05-09.

3. Newcomb W D, Rimstidt J D, Appl Geochem., 2002, 17(1), 49-57; DOI:10.1016/S0883-2927(01)00089-0

4. Onwuka F O, Ujuanbi O and Molua O C, Pacific J Sci Tech., 2011, 12(1), 560-565.

5. WHO. Guidelines for drinking water quality. Recommendations. $3^{\text {rd }}$ Ed., Geneva, 2008, 1.

6. Khan M, Im Y-B, Shunmugavel A, Gilg A G, Dhindsa R K, Singh A K and Singh I, $J$ Neuroinflammation, 2009, 6, 32; DOI:10.1186/1742-2094-6-32

7. NPC, National Population Commission. 2006 Population Census Figure, 2006.

8. APHA, Standard methods for the examination of water and waste water. $20^{\text {th }}$ Edition, American Public Health Association, Washington DC, USA, 1998, 15-20.

9. Duncan D B, Biometrics, 1955, 11(1), 1-42.

10. Greenhouse J P and Haris R D, J Hydrol., 1983, 63(1-2), 177-197; DOI:10.1016/0022-1694(83)90227-5

11. NAS/IOM, National Academy of Sciences/Institute of Medicine. Dietary reference intakes for Vitamin A, Vitamin K, arsenic, boron, chromium, copper, iodine, iron, manganese, molybdenum, nickel, silicon, vanadium, and zinc. Food and Nutrition Board, Institute of Medicine, Washington, DC, http://www.nap.edu/catalog/10026.html 
12. Maher T J, Medication, Alcohol Consumption and Magnesium: Ensuring Adequate Intake of Oral Magnesium. In the Magnesium Website Online Library. The Magnesium Report. Clinical Research and Laboratory News for Cardiologists, Second Quarter, 2000, Accessed September 15, 2012.

13. Sketchell $\mathrm{J}$ and Shaheen N, Ground water quality in rural Saskatchewan- Emerging issues for drinking water. In the Proceedings of the $9^{\text {th }}$ National Conference on Drinking Water, 1999

14. Longe E O and Enekwechi L O, Int J Env Sci Tech., 2007, 4(1), 133-140; DOI:10.1007/BF03325971

15. Patil G and Ahmad I, Acta Chim Pharm Indica., 2011, 1(1), 7-9.

16. Kanwar K C and Sharma S, Sci Rep., 1987, 586.

17. Oyekunle J A O, Ogunfowokan A O, Torto $\mathrm{N}$ and Akanni $\mathrm{M}$ S, J Int Env Appl Sci., 2011, 6(4), 483-496.

18. Shuhaimi-Othman M, Pascoe D, Borgmann Andw U and Norwood N, Environ Monit Assess., 2006, 117(1-3), 27-44; DOI:10.1007/s10661-006-7674-6

19. Xia Y and Liu J, Toxicol., 2004, 198(1-3), 25-29; DOI:10.1016/j.tox.2004.01.016

20. Liu, C W, Lin K H, Kuo Y M, Sci Tot Environ., 2003, 313(1-3), 77-89; DOI:10.1016/S0048-9697(02)00683-6

21. Siddiq S, Sustainable Development Policy. Annual Report 2003-04. India Institute of Technology Kanpur; http://www.iitk.ac.in/olddord/AnnualReport03_04.pdf

22. Akoteyon I S, Mbata U A and Olalude G A, J Appl Sci Env San., 2011, 6(2), 155-163.

23. Knudso E J, Dvewer D L, Christian J D and Larson T V, Application of factor analysis to the study of rain Chemistry in the Puget Sound region. In: Kowalski BR (Ed) Chemometrics: theory and application. ACS symposium series, Washington DC, 1977, p80.

24. Olutona G O, Aribisala O G, Akintunde E A and Obimakinde S O, Terr Aquat Env Toxicol., 2012, 6(2), 116-126.

25. Hopke P K, Receptor Modelling in Environmental Chemistry, Wiley, USA, 1985. 